\title{
Comparing the Effectiveness of Topical Fluoride and Povidone Iodine with Topical Fluoride Alone for the Prevention of Dental Caries among Children: A Systematic Review and
} Meta-analysis

\author{
Arpit Gupta ${ }^{1}$, Nishant ${ }^{2}$, Shweta Sharda ${ }^{3}$, Amit Kumar $^{4}$, Ashima Goyal ${ }^{5}$, Krishan Gauba ${ }^{6}$
}

\begin{abstract}
Background: Combined use of povidone iodine (PI) along with topical fluorides (TF) has been suggested as a promising strategy to reduce dental caries incidence and cariogenic bacterial load. However, the available literature presents mixed evidence regarding its effectiveness as compared to TF application alone.

Aim and objective: 'TF + PI' vs TF alone in the prevention of dental caries among 1-12-year-old children assessed through caries increment and mean S. mutans and Lactobacillus counts.

Materials and methods: Five databases (Cochrane Central Register of Controlled Trials, EBSCOhost, PubMed/Medline, Scopus, and Web of Science) were searched for relevant literature. Out of 72 studies that were screened, 7 eligible studies were included out of which 4 studies were subjected to meta-analysis. The generic inverse variance test was used to assess the primary outcome reported as mean \pm SD/ events occurred (caries incidence), whereas for mean post-intervention S. mutans colony count, inverse variance function was used. The Cochrane's Collaboration tool and Modified Downs and Black scoring criteria were used to evaluate the quality of the included articles. Heterogeneity across the studies was assessed using the $l^{2}$ statistic. Statistical significance was set at $p<0.05$.

Results: Overall, for primary and permanent dentition combined, the dental caries incidence was found to be significantly lower in the 'TF + $\mathrm{PI}$ combined therapy group as compared to TF alone [SMD $-0.4(-0.78$ to -0.03$), p=0.04]$. The two groups showed no significant difference with respect to post-intervention $S$. mutans count [SMD $-0.1(-0.57$ to +0.37$), p=0.69]$. No study was found that compared post-intervention Lactobacillus count between the two groups.

Conclusion: Based on the pooled analysis from the limited literature available, there is a very low quality of evidence that 'TF + PI' combined therapy is more effective in the prevention of new caries lesions among 1-12-year-old children as compared to TF use alone. Future clinical trials with robust methodologies are recommended to generate conclusive evidence.

Clinical significance: PI application might exert an added benefit with TF in preventing the occurrence of new carious lesions among 1-12-yearold children.

Keywords: Dental caries, Lactobacillus, Meta-analysis, Mutans Streptococci, Povidone-iodine, Systematic review, Topical fluorides.

International Journal of Clinical Pediatric Dentistry (2020): 10.5005/jp-journals-10005-1844
\end{abstract}

\section{INTRODUCTION}

Dental caries is an easily preventable yet highly prevalent condition worldwide and thus constitutes a significant public health problem. ${ }^{1,2}$ The conventional restorative treatment for tooth decay exerts an enormous financial burden on an individual. ${ }^{3}$ Moreover, it has been reported that general anesthesia is usually required for treatment of severe early childhood caries, and it may increase the risk of morbidity and/or mortality. ${ }^{4}$ Patient-dependent behavioral modification focusing on healthy diet and good oral hygiene practices cannot be solely relied upon for prevention of dental caries. Thus, intensive preventive interventions that do not depend upon patient compliance should be adopted. ${ }^{5}$

The imbalance between the protective and pathogenic factors as the primary mechanism of dental caries causation is well documented in the literature. ${ }^{6}$ Evidence suggests that professionally applied topical fluoride (TF) is highly effective in preventing dental caries by strengthening the protective factors. ${ }^{3,7}$ The primary mechanism of action of TF is by enhancing the remineralization process and inhibiting the demineralization process. ${ }^{8}$ However, it is noted that the effectiveness of fluoridated
${ }^{1-6}$ Oral Health Sciences Centre, Postgraduate Institute of Medical Education and Research, Chandigarh, India

Corresponding Author: Arpit Gupta, Oral Health Sciences Centre, Postgraduate Institute of Medical Education and Research, Chandigarh, India, Phone: +91 8826674284, e-mail: arpitg.in@gmail.com

How to cite this article: Gupta A, Nishant, Sharda S, et al. Comparing the Effectiveness of Topical Fluoride and Povidone lodine with Topical Fluoride Alone for the Prevention of Dental Caries among Children: A Systematic Review and Meta-analysis. Int J Clin Pediatr Dent 2020;13(5):559-565.

Source of support: Nil

Conflict of interest: None

compounds is low in episodes of low pH stress and a more holistic approach is necessary to control caries progression and prevent caries occurrence effectively. ${ }^{9}$ To limit down the pathogenic factors, use of antimicrobial agents as an adjunct to TF therapy is implicated to be an effective caries preventive regimen. ${ }^{10}$ The water-soluble 
povidone-iodine $(\mathrm{PI})$ solution is known to exert caries preventive effect owing to its long-term preferential and antimicrobial action against $S$. mutans due to the slow release of iodine. ${ }^{11}$ Various trials have assessed the added benefit of using PI in preventing dental caries but with inconclusive evidence.

In this era of evidence-based dentistry, there is a need to draw conclusive evidence regarding combined use of topical fluoride and povidone-iodine ('TF + PI') over TF alone, which may alter the current clinical practices and may guide the future preventive programs. Thus, the aim of this study is to compare the effectiveness of 'TF + PI' with TF alone for the prevention of dental caries among 1-12-year-old children.

\section{Materials and Methods}

The present study was registered with PROSPERO (CRD42019134530).

\section{Search Strategy}

Cochrane, EBSCOhost, PubMed/Medline, Scopus, and Web of Science were electronically searched in March 2019 to identify the published literature that assessed the effectiveness of 'TF + PI' application on dental caries in children. The keywords used for literature search were "topical fluoride," "povidone-iodine," "dental caries," "early childhood caries," "Lactobacillus," and "Mutans streptococci" along with the use of Boolean operators (AND/OR) as required. Manual search of cross-references was done to identify additional records, if any. All the records obtained were exported to the Endnote X9 software for removing the duplicates and further screening and selection based on the inclusion-exclusion criteria. Assessment of records for possible inclusion was done in two phases; the first phase included the screening of titles and abstracts and was done independently by two authors ('NT' and 'SS'). The second phase involved scrutiny of the full texts and was done by the same two authors independently ('NT' and 'SS'). Discrepancies were discussed in the presence of third author ('AG') and decisions were made unanimously.

\section{Inclusion Criteria}

Retrospective/prospective cohort studies, randomized and nonrandomized controlled trials published in the English language were included. The studies that evaluated the effect of 'TF + PI' application (experimental group) vs TF alone/placebo (control group) among 1-12-year-old children on the dental caries status, S. mutans count, and Lactobacillus count were included.

\section{Exclusion Criteria}

Cross-sectional studies, analytical studies (case-control/cohort), in vitro studies, animal trials, narrative/systematic reviews, case reports, and letters to the editor were excluded.

\section{Outcome Variables}

The primary outcome variable was new carious lesions at a minimum of 1-year follow-up. Additionally, mean S. mutans and Lactobacillus counts at a minimum of 2 weeks post-intervention in the experimental group vs the control group were assessed.

\section{Data Extraction and Qualitative Assessment of Included Studies}

Two examiners ('NT' and 'AK') independently extracted data using a specially designed form that collected information on the study characteristics such as location, design, population, intervention, outcome variables assessed, and the results reported. The quality of the articles was evaluated using two criteria. First, the Cochrane Collaboration's tool was used in which the articles were scaled for assessing selection, performance, detection, attrition, reporting, and other risks of bias. ${ }^{12}$ Second, the study quality was also evaluated using the modified Downs and Black scoring criteria. ${ }^{13}$ The 27 -item modified Down's and Black checklist consists of five subscales, namely Reporting, External Validity, Internal Validity (Bias), Confounding (Selection Bias), and Power and has a maximum score of 28 . Based on the scores obtained, each study was graded as "excellent" (24-28), "good" (19-23), "fair" (14-18), or "poor" (<14).

\section{Statistical Analysis}

Data from five studies were subjected to meta-analysis using Review Manager (version 5.3). For the primary outcome data from four studies that reported caries incidence as events occurred and one study that reported decay as mean \pm SD was pooled together using generic inverse variance function. The subgroup analysis was done for deciduous dentition ${ }^{14,15}$ and permanent dentition ${ }^{16,17}$ separately. For the post-treatment $S$. mutans count reported as a continuous variable, the inverse variance test was used to compare the experimental and control groups. Heterogeneity among the studies was evaluated using the $l^{2}$ statistic. The random effect model was used to carry out the pooled analysis. The $p$ value $<0.05$ was set as the statistical significance limit.

\section{Results}

Through the electronic search, 120 records were identified. After removing 48 duplicate references, 72 studies were assessed for eligibility. Sixty-four were excluded after the title and abstract screening in the first phase. In the second phase, one study was excluded after full-text reading. Finally, seven articles were included in qualitative analysis out of which data from five studies were synthesized quantitatively. The systematic review process is shown in PRISMA flowchart ${ }^{18}$ (Flowchart 1).

\section{Study Characteristics}

Table 1 summarizes the characteristics of the seven included studies. All studies were published between 2005 and 2016 and had children at high risk of dental caries except for El-Housseiny et al. ${ }^{5}$ that included healthy children.

El-Housseiny et al. ${ }^{5}$ and Zhan et al. ${ }^{14}$ used $1.23 \%$ acidulated phosphate fluoride (APF) gel and PI combined therapy; Xu et al. ${ }^{17}$ applied fluoride foam and PI; Milgrom et al., ${ }^{15}$ Reilly et al., ${ }^{19}$ and Tut et al. ${ }^{16}$ applied 5\% sodium fluoride varnish and Pl; Hashemi et al. ${ }^{20}$ applied a mixture of $0.2 \%$ sodium fluoride varnish and PI. Thus, in all the included studies, TF $+10 \% \mathrm{PI}$ application was made in the experimental group.

None of the studies reported a low risk of bias. Xu et al. ${ }^{17}$ had an overall unclear risk of bias due to incomplete reporting of blinding and loss to follow-up of the study participants. The retrospective cohort study by Tut et al. ${ }^{16}$ was noted having a high risk of bias for all the domains except for attrition bias and reporting bias. The quasi-experimental research by Milgrom et al. ${ }^{15}$ had an overall high risk of bias. The Downs and Black quality assessment scores of the included studies ranged from 15 to 21. Three studies were graded "fair" "good". ${ }^{16,17}$ For the studies subjected to meta-analysis, the Risk of Bias Assessment is shown in Figure 1, and the Downs and Black scores are shown in Table 2. 
Flowchart 1: PRISMA flow diagram showing systematic review process

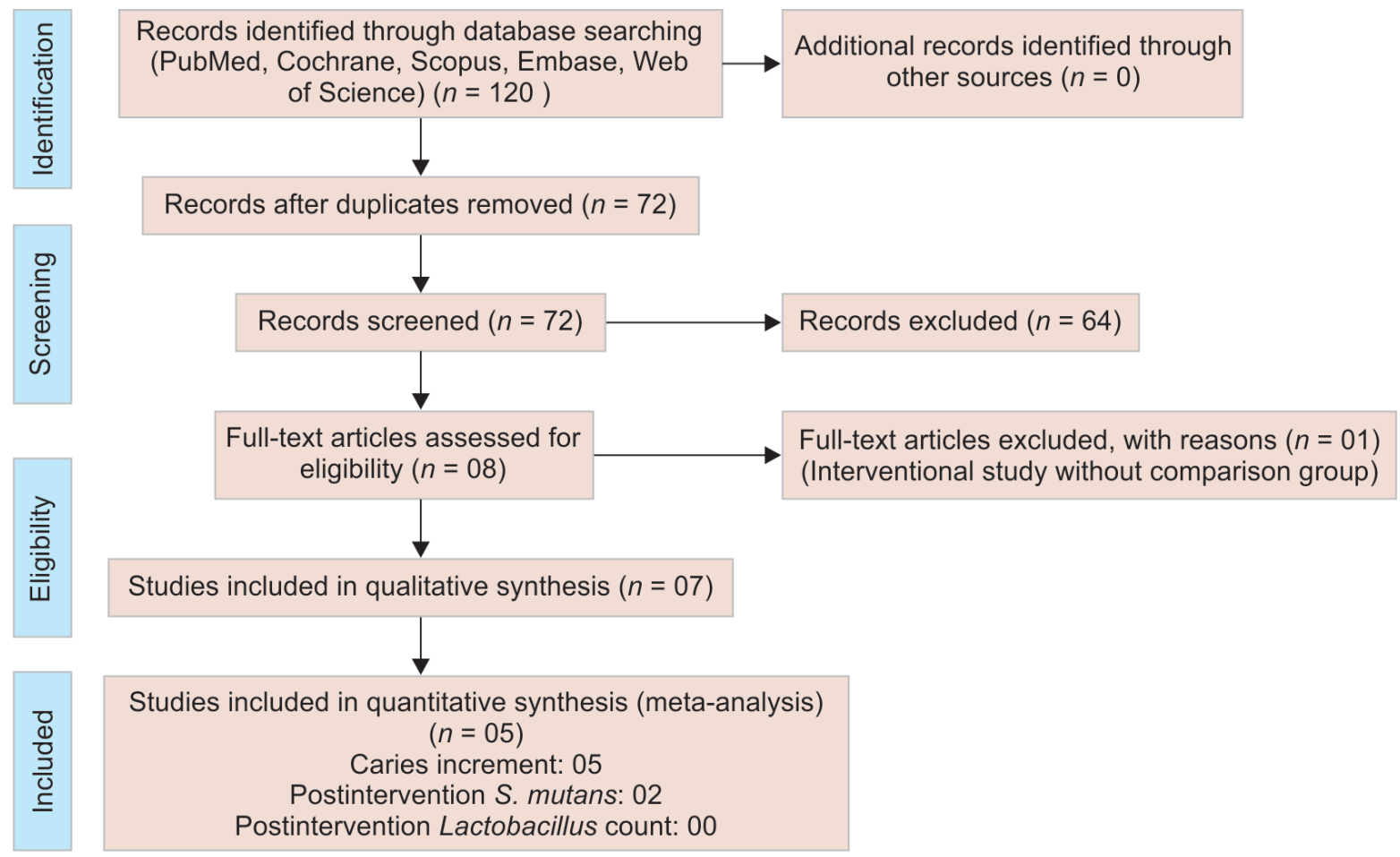

\section{Primary Outcome}

Overall, the pooled analysis showed a lower risk of caries incidence in 'TF + Pl' combined therapy compared to TF use alone [SMD $-0.4(-0.78$ to -0.03$\left.), p=0.04 ; I^{2}=28 \%, p=0.24\right]$. For the subgroup analysis, no significant difference is observed between the experimental and control group in deciduous teeth [SMD $-0.19(-0.65$ to 0.26$\left.), p=0.41 ; 1^{2}=17 \%, p=0.3\right]$, whereas, the pooled analysis is seen to significantly favor combined therapy in permanent teeth [SMD $-0.71(-1.15$ to -0.28$), p=0.001 ; \mathrm{I}^{2}=0 \%$, $p=0.83$ ] (Fig. 1).

\section{Secondary Outcome}

The pooled analysis of 37 participants in the 'TF + PI' group and 33 in the TF group from two studies was performed for mean post-intervention S. mutans counts. Although the meta-analysis was noted to favor the 'TF + PI' application, the difference was not significant [SMD $\left.-0.1(-0.57,+0.37), p=0.69,\left(I^{2}=0 \% ; p=0.49\right)\right]$ (Fig. 2).

\section{Discussion}

The present review favors 'TF + PI' application over TF use alone in reducing the incidence of dental carious lesions. While, Cochrane reviews $s^{21,22}$ suggest that TF application is effective in reducing caries incidence in children and adolescents, Buzalaf et al. ${ }^{23}$ have reported that although fluoride exhibits bactericidal effects on S. mutans in vitro, yet convincing evidence is lacking regarding the clinical effects of fluoride-containing oral-care products on S. mutans. Additional use of an antibacterial agent is suggested to exert an added benefit in reducing oral pathogenic bacteria. ${ }^{24}$ The US FDA has regarded $10 \% \mathrm{PI}$ safe enough to be applied on the skin and mucous membrane as a presurgical disinfectant. ${ }^{25}$ None of the studies have reported any side effects of PI use and its use has been found to be well accepted by children.

Although the studies included in this review have used different delivery vehicles for the application of TF, yet literature concludes that there is no difference in the caries-preventive effectiveness on using fluoride in solution, gel, or varnish form. ${ }^{26}$ Thus, pooling of results seems to be justified irrespective of the TF delivery vehicle used. Moreover, to account for the heterogeneity across the studies, a random-effects model was used.

Among the included studies, the frequency of 'TF $+\mathrm{PI}$ ' application varied from single to 12 per year. Results of a systematic review concluded that the biannual application of TF reduces the chances of new tooth decay by approximately $30 \% .{ }^{27}$ The American Academy of Pediatric Dentistry guidelines suggests the quarterly application of fluoride varnish can significantly prevent dental caries in the high-risk group. ${ }^{28}$

Hashemi et al. used a mixture of $\mathrm{PI}$ and $0.02 \% \mathrm{NaF}$ solution as the active ingredients (iodine and fluoride) do not react with each other and are thus available in free form for their therapeutic action. ${ }^{20}$ Other studies included in the present review have applied PI solution followed by TF.

Since the Cochrane Collaboration's tool is primarily used to assess the risk of bias of randomized controlled trials, the risk of bias evaluated for the retrospective cohort study by Tut et al. ${ }^{16}$ and quasiexperimental trial by Milgrom et al. ${ }^{15}$ holds limited relevance. To assess the quality of all the trials subjected to quantitative analysis, the Downs and Black criterion was also used as it is designed to evaluate both randomized and nonrandomized studies. This criterion has superior internal consistency, acceptable test-retest reliability, and validity (face and criterion). ${ }^{13}$ 
Table 1: Characteristics of included studies

\begin{tabular}{|c|c|c|c|c|c|c|c|}
\hline Author, year & $\begin{array}{l}\text { Study design, } \\
\text { Study location } \\
\text { (country) }\end{array}$ & $\begin{array}{l}\text { Target popula- } \\
\text { tion }\end{array}$ & $\begin{array}{l}\text { Experimental } \\
\text { group intervention }\end{array}$ & $\begin{array}{l}\text { Control group } \\
\text { intervention }\end{array}$ & $\begin{array}{l}\text { Outcome vari- } \\
\text { ables }\end{array}$ & $\begin{array}{l}\text { Follow-up, } \\
\text { period }\end{array}$ & Summary of findings \\
\hline \multicolumn{8}{|c|}{ Acidulated phosphate fluoride (APF) gel and povidone iodine (PI) } \\
\hline $\begin{array}{l}\text { El-Housseiny } \\
\text { and Farsi } 2005\end{array}$ & $\begin{array}{l}\text { Two-arm, paral- } \\
\text { lel, clinical trial } \\
\text { Saudi Arabia }\end{array}$ & $\begin{array}{l}\text { 4-6-year- } \\
\text { old healthy } \\
\text { children }\end{array}$ & $\begin{array}{l}N=27,1.23 \% \\
\text { APF gel applied } \\
\text { at baseline visit } \\
\text { followed by ap- } \\
\text { plication of } 10 \% \\
\text { PI solution every } \\
\text { week for one } \\
\text { month; then the } \\
\text { gel and povidone } \\
\text { iodine were ap- } \\
\text { plied alternately } \\
\text { every } 3 \text { months } \\
\text { for one year. }\end{array}$ & $\begin{array}{l}N=27,1.23 \% \\
\text { APF gel ap- } \\
\text { plication at } \\
\text { baseline then } \\
\text { once a week } \\
\text { application for } \\
\text { a month. This } \\
\text { was followed by } \\
\text { one application } \\
\text { every } 3 \text { months } \\
\text { for one year. }\end{array}$ & $\begin{array}{l}\mathrm{dmft}, S \text { mutans } \\
\text { and lactobacil- } \\
\text { lus count }\end{array}$ & $\begin{array}{l}1,3,6 \text { and } \\
12 \text { months }\end{array}$ & $\begin{array}{l}\text { No statistically } \\
\text { significant differ- } \\
\text { ence for dmft and } \\
\text { bacterial counts. }\end{array}$ \\
\hline $\begin{array}{l}\text { Zhan et al. } \\
2006\end{array}$ & $\begin{array}{l}\text { Two-arm, paral- } \\
\text { lel, randomized } \\
\text { clinical trial USA }\end{array}$ & $\begin{array}{l}\text { 2-6-year } \\
\text { old healthy } \\
\text { children } 11 \\
\text { per group }\end{array}$ & $\begin{array}{l}N=11, \text { Oral } \\
\text { prophylaxis }+ \\
\text { complete restora- } \\
\text { tive therapy }+ \\
2-\mathrm{mL} \mathrm{PI} \mathrm{applica-} \\
\text { tion }+1.23 \% \text { APF } \\
\text { gel application }\end{array}$ & $\begin{array}{l}N=11, \text { Oral } \\
\text { prophylaxis } \\
+ \text { complete } \\
\text { restorative } \\
\text { therapy + 2-mL } \\
\text { phosphate } \\
\text { buffer solution } \\
\text { application + } \\
1.23 \% \text { APF gel } \\
\text { application }\end{array}$ & $\begin{array}{l}\text { Change in } S \text {. } \\
\text { mutans, Lacto- } \\
\text { bacillus count } \\
\text { and incidence } \\
\text { of dental caries }\end{array}$ & $\begin{array}{l}1 \text { hour, } 3 \\
\text { weeks, } 3 \\
\text { months, and } \\
1 \text { year }\end{array}$ & $\begin{array}{l}\text { No statistically } \\
\text { significant differ- } \\
\text { ence was observed } \\
\text { in-between the two } \\
\text { groups }\end{array}$ \\
\hline \multicolumn{8}{|c|}{ Fluoride foam and PI } \\
\hline Xu et al. 2009 & $\begin{array}{l}\text { Two-arm, paral- } \\
\text { lel randomized } \\
\text { controlled clini- } \\
\text { cal trial China }\end{array}$ & $\begin{array}{l}\text { 6-9-year old } \\
\text { high-risk } \\
\text { children }\end{array}$ & $\begin{array}{l}N=30,10 \% \text { PVP-I } \\
\text { and fluoride foam } \\
\text { in } 30 \text { subjects- } \\
\text { once a week for } 4 \\
\text { weeks }\end{array}$ & $\begin{array}{l}N=31, \text { Fluoride } \\
\text { foam in } 31 \\
\text { subjects-once } \\
\text { a week for } 4 \\
\text { weeks }\end{array}$ & $\begin{array}{l}\text { S, mutans } \\
\text { count, Lacto- } \\
\text { bacillus counts, } \\
\text { and dental car- } \\
\text { ies incidence }\end{array}$ & $\begin{array}{l}2,6, \text { and } 12 \\
\text { months }\end{array}$ & $\begin{array}{l}\text { No statistically } \\
\text { significant differ- } \\
\text { ence between the } \\
\text { groups for the out- } \\
\text { come variables. }\end{array}$ \\
\hline \multicolumn{8}{|c|}{ Fluoride varnish (FV) and PI } \\
\hline Tut et al. 2010 & $\begin{array}{l}\text { Retrospective } \\
\text { Cohort study } \\
\text { USA }\end{array}$ & $\begin{array}{l}\text { 5-7-year-old } \\
\text { high risk } \\
\text { children }\end{array}$ & $\begin{array}{l}N=428,10 \% \mathrm{PI} \\
\text { followed by } \mathrm{NaF} \\
\text { varnish-three } \\
\text { times per year }\end{array}$ & $\begin{array}{l}N=186, \mathrm{FV}- \\
\text { three times per } \\
\text { year }\end{array}$ & $\begin{array}{l}\text { Decay }(D) \text { in } \\
\text { first permanent } \\
\text { molars. }\end{array}$ & 1 year & $\begin{array}{l}88.3 \% \text { children in } \\
\text { experimental group } \\
\text { and } 78.5 \% \text { children } \\
\text { in control group } \\
\text { had caries-free first } \\
\text { permanent molars }\end{array}$ \\
\hline $\begin{array}{l}\text { Milgrom et al. } \\
2011\end{array}$ & $\begin{array}{l}\text { Quasi Experi- } \\
\text { mental study } \\
\text { USA }\end{array}$ & $\begin{array}{l}\text { 1-2.5-year- } \\
\text { old high risk } \\
\text { children }\end{array}$ & $\begin{array}{l}N=81,0.2 \mathrm{~mL} \\
1 \% \text { PI followed by } \\
5 \% \text { NaF Varnish } \\
\text { application-three } \\
\text { times per year. }\end{array}$ & $\begin{array}{l}N=90,5 \% \mathrm{NaF} \\
\text { Varnish-three } \\
\text { times per year. }\end{array}$ & $\begin{array}{l}\text { New decay }(d) \\
\text { in primary teeth }\end{array}$ & 1 year & $\begin{array}{l}41 \% \text { in the experi- } \\
\text { mental group and } \\
54 \% \text { in the control } \\
\text { group had devel- } \\
\text { oped new decay in } \\
\text { primary teeth. }\end{array}$ \\
\hline $\begin{array}{l}\text { Hashemi et al. } \\
2015\end{array}$ & $\begin{array}{l}\text { Double-blind, } \\
\text { clinical trial Iran }\end{array}$ & $\begin{array}{l}\text { 4-6-year-old } \\
\text { high risk } \\
\text { children }\end{array}$ & $\begin{array}{l}N=37, \text { A mixture } \\
\text { of } 10 \% \mathrm{PI} \text { and } \\
0.2 \% \mathrm{NaF} \text { was ap- } \\
\text { plied once a week } \\
\text { for three months }\end{array}$ & $\begin{array}{l}N=37, \text { Pla- } \\
\text { cebo-once a } \\
\text { week for three } \\
\text { months. }\end{array}$ & $\mathrm{dmft}$ & 6 months & $\begin{array}{l}68 \% \text { of the teeth in } \\
\text { experimental group } \\
\text { and } 6.3 \% \text { in control } \\
\text { group showed car- } \\
\text { ies arrest. }\end{array}$ \\
\hline $\begin{array}{l}\text { Reilly et al. } \\
2016\end{array}$ & $\begin{array}{l}\text { Single arm } \\
\text { double baseline } \\
\text { clinical trial USA }\end{array}$ & $\begin{array}{l}\text { 6-12-year- } \\
\text { old high risk } \\
\text { children }\end{array}$ & $\begin{array}{l}N=12, \text { One ap- } \\
\text { plication of } 10 \% \\
\text { povidone iodine } \\
\text { and } 5 \% \text { NaF var- } \\
\text { nish application. }\end{array}$ & $\begin{array}{l}N=12, \text { Nega- } \\
\text { tive control } \\
\text { (no treatment } \\
\text { given). }\end{array}$ & $\begin{array}{l}\text { Microbiome } \\
\text { plaque ecology }\end{array}$ & 1 week & $\begin{array}{l}\text { Not much change } \\
\text { was observed in the } \\
\text { overall diversity in } \\
\text { the plaque biofilm. } \\
\text { However, an } \\
80-90 \% \text { reduction } \\
\text { in the plaque bio- } \\
\text { film accumulation } \\
\text { was noted after PI/ } \\
\text { TF application. }\end{array}$ \\
\hline
\end{tabular}




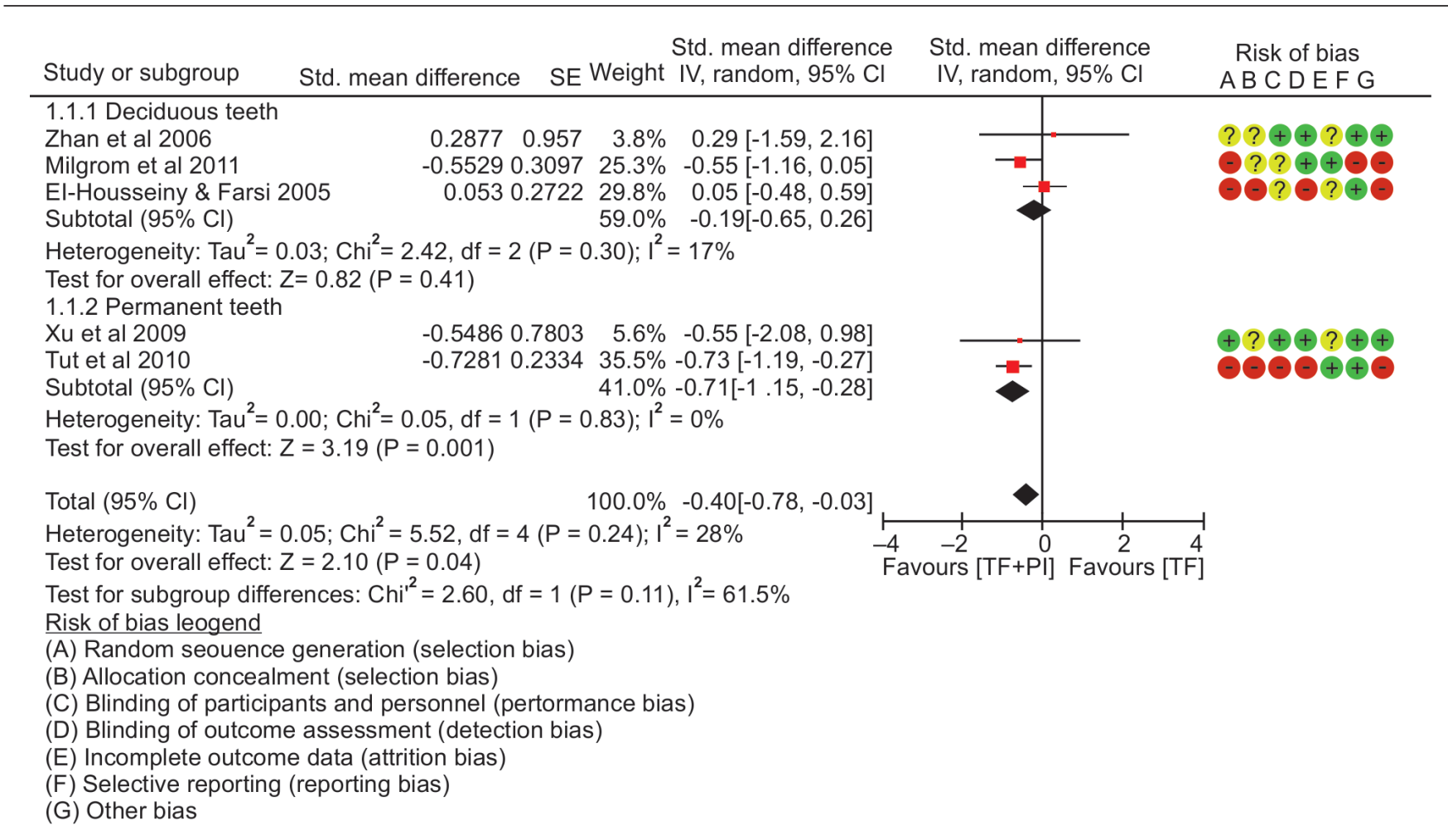

Fig. 1: Meta-analysis for deciduous and permanent teeth on dental caries increment

Table 2: Summary chart for downs and black scoring (grading)

\begin{tabular}{ll}
\hline Author, year & Downs and black scores (grades) \\
\hline El Housseiny et al. 2005 & 15 (fair) \\
Hashemi et al. 2015 & 20 (good) \\
Milgrom et al. 2011 & 21 (good) \\
Reilly et al. 2016 & 17 (fair) \\
Tut et al. 2010 & 18 (fair) \\
Xu et al. 2009 & 20 (good) \\
Zhan et al. 2006 & 21 (good) \\
\hline
\end{tabular}

Marinho et al. ${ }^{22}$ in a comparative analysis between fluoride varnish vs placebo or no treatment group reported a statistically significant pooled caries prevented fraction estimate of $43 \%$ in permanent teeth and $37 \%$ in deciduous teeth. This evidence having a statistically significant heterogeneity has been reported to be of moderate quality. In the present review, for the permanent teeth subgroup analysis, a statistically significant $45 \%$ risk reduction in caries increment was noted in the 'TF + PI' group compared to TF use alone. In deciduous teeth, however, the $21 \%$ risk reduction favoring the experimental group over TF use alone was not found to be statistically significant. Hashemi et al. ${ }^{20}$ using a split-mouth design in 4-6-year old demonstrated $68 \%$ caries arrest in the combined therapy group compared to only $6.3 \%$ caries arrest in the control group. PI can thus be seen to have an added benefit with TF in the prevention of dental caries, especially in the permanent teeth.

No difference was observed in-between the experimental and control groups for post-treatment S. mutans count. ${ }^{14,17}$ This could be attributed to the restorations of the caries lesions and extractions or improvement in oral hygiene practices of both the experimental group and control group population. On the contrary, Milgrom et al. ${ }^{15}$ found 'TF + PI' combined use to be more effective than TF alone in reducing bacterial count in primary teeth. The limited follow-up, small sample, along with nonrandomization limit the generalizability of this study results. ${ }^{15}$ Single application of $5 \% \mathrm{NaF}$ varnish and $10 \% \mathrm{PI}$ among high-risk children of $6-12$-year-old by Reilly et al. ${ }^{19}$ showed a subtle change in the plaque ecology in just 1 week, although no drastic dysbacteriosis within dental plaque was noted.

Although $P^{2}$ statistic for the primary and secondary outcome assessment showed low/no heterogeneity, there exists some variation among the included studies with respect to variation in study design, methodology, different follow-up period, and the frequency of application of the agents. The results of this review should be interpreted cautiously. Also, it is recognized that it takes nearly 18 months before the carious lesion can be clinically detected with conventional methods. Therefore, the pooled analysis of the included studies with at least 1-year follow-up might have underreported the primary outcome in both the groups.

Furthermore, due to nonreporting of data on caries determinants such as demographic details, socioeconomic status of the study population, sugar consumption, etc., a multivariate analysis could not be used in the meta-analysis function. Given the multifactorial nature of dental caries, the odds ratio calculated might have underor overestimated the effectiveness of 'TF + PI' application. The paucity of randomized trials that assessed the caries preventive effectiveness evaluated through post-intervention Lactobacillus count also limited the pooling of the secondary outcome variable as desired. Taking the limitations into account, future randomized controlled trials with robust methodology are recommended to compare the effect of combined application of 'TF + PI' and TF alone.

Authors await the results of a randomized controlled trial by Milgrom et al. ${ }^{29}$ planned to assess the efficacy of a combination of PI and sodium fluoride dental varnish application in the prevention of new caries lesions with a 2-year follow-up (NCT03082196). Authors 


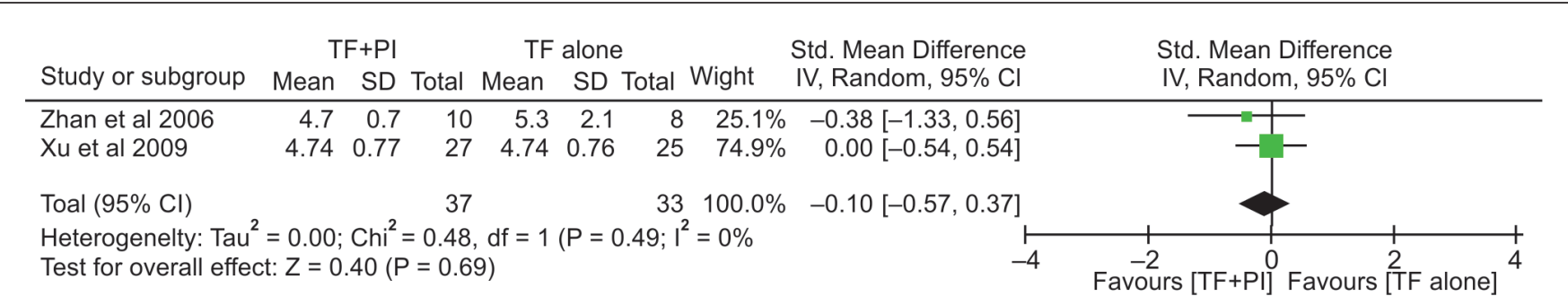

Fig. 2: Meta-analysis for post-treatment S. mutans count

also await the results of a pragmatic, controlled trial aimed to assess the effectiveness of a specially designed oral healthcare package comprising of quarterly application of 'TF + PI' and oral health education on oral health status among children of aged 1-6 years (CTRI/2019/02/017556). ${ }^{30}$

\section{Conclusion}

The findings of this review indicate very low-quality evidence that combined application of 'TF + PI' has better caries preventive effectiveness compared to TF use alone. Moreover, the limited number of studies with low internal and external validities limits the generalizability of results obtained. Therefore, future clinical trials with longer follow-up period, larger sample size, and robust methodologies are recommended in order to generate conclusive evidence.

\section{References}

1. Bagramian RA, Garcia-Godoy F, Volpe AR. The global increase in dental caries. A pending public health crisis. Am J Dent 2009;22(1): 3-8.

2. Sadat Sajadi F, Moradi M, Pardakhty A, et al. Effect of fluoride, chlorhexidine and fluoride-chlorhexidine mouthwashes on salivary streptococcus mutans count and the prevalence of oral side effects. J Dent Res Dent Clin Dent Prospects 2015;9(1):49-52. DOI: 10.15171/ joddd.2015.010.

3. Gao SS, Zhang S, Mei ML, et al. Caries remineralization and arresting effect in children by professionally applied fluoride treatment - a systematic review. BMC Oral Health 2016;16(1):12. DOI: 10.1186/ s12903-016-0171-6.

4. Ammari JB, Baqain ZH, Ashley PF. Effects of programs for prevention of early childhood caries. A systematic review. Med Princ Pract 2007;16(6):437-442. DOI: 10.1159/000107748.

5. El-Housseiny A, Farsi N. The effectiveness of two antibacterial regimens on salivary mutans Streptococci and lactobacilli in children. J Clin Pediatr Dent 2005;30(2):145-151. DOI: 10.17796/jcpd.30.2.w352 $6518 \mathrm{n} 0 \mathrm{~m} 45557$.

6. Featherstone JD. Dental caries: a dynamic disease process. Aust Dent J 2008;53(3):286-291. DOI: 10.1111/j.1834-7819.2008.00064.x.

7. Bonetti D, Clarkson JE. Fluoride varnish for caries. Prevention: Efficacy Implementat Caries Res 2016;50(Suppl 1):45-49.

8. Kanduti D, Sterbenk P, Artnik B. Fluoride: a review of use and effects on health. Mater Sociomed 2016;28(2):133-137. DOI: 10.5455/ msm.2016.28.133-137.

9. Lussi A, Hellwig E, Klimek J. Fluorides - mode of action and recommendations for use. Schweiz Monatsschr Zahnmed 2012;122(11):1030-1042.

10. Ten Cate JM. International conference on novel anti-caries and remineralizing agents. Vina del mar, Chile, January 10-12, 2008. Preface Adv Dent Res 2009;21(1):3. DOI: 10.1177/0895937 409335588.
11. Furiga A, Dols-Lafargue M, Heyraud A, et al. Effect of antiplaque compounds and mouth rinses on the activity of glucosyl transferases from Streptococcus sobrinus and insoluble glucan production. Oral Microbiol Immunol 2008;23(5):391-400. DOI: 10.1111/j.1399302X.2008.00441.x.

12. Higgins JPT, Altman DG, Gotzsche PC, et al. The cochrane collaboration's tool for assessing risk of bias in randomized trials. BMJ 2011;343(oct18 2):d5928. DOI: 10.1136/bmj.d5928.

13. Downs SH, Black N. The feasibility of creating a checklist for the assessment of the methodological quality both of randomized and non-randomized studies of health care interventions. J Epidem Commun Health 1998;52(6):377-384. DOI: 10.1136/jech.52.6.377.

14. Zhan L, Featherstone JDB, Gansky SA, et al. Antibacterial treatment needed for severe early childhood caries. J Public Health Dent 2006;66(3):174-179. DOI: 10.1111/j.1752-7325.2006.tb02576.x.

15. Milgrom PM, Tut OK, Mancl LA. Topical iodine and fluoride varnish effectiveness in the primary dentition: a quasi-experimental study. J Dent Child (Chic) 2011;78(3):143-147.

16. Tut OK, Milgrom PM. Topical iodine and fluoride varnish combined is more effective than fluoride varnish alone for protecting erupting first permanent molars: a retrospective cohort study. J Public Health Dent 2010;70(3):249-252. DOI: 10.1111/j.1752-7325.2010.00163.x.

17. Xu X, Li JY, Zhou XD, et al. Randomized controlled clinical trial on the evaluation of bacteriostatic and cariostatic effects of a novel povidone-iodine/fluoride foam in children with high caries risk. Quintessence Int 2009;40(3):215-223.

18. Moher D, Liberati A, Tetzlaff J, et al. Preferred reporting items for systematic reviews and meta-analyses: the PRISMA statement. Ann Intern Med 2009;151(4):264-269. DOI: 10.7326/0003-4819-151-4200908180-00135.

19. Reilly C, Goettl M, Steinmetz M, et al. Short-term effects of povidone iodine and sodium fluoride therapy on plaque levels and microbiome diversity. Oral Dis 2016;22(2):155-161. DOI: 10.1111/odi.12407.

20. Hashemi Z, Malek Mohammadi T, Poureslami H, et al. The effect of topical iodine and fluoride varnish combination in preventing early childhood caries: a pilot study. J Dent Mat Techniq 2015;4(4):167-172.

21. Marinho VC, Worthington HV, Walsh T, et al. Fluoride gels for preventing dental caries in children and adolescents. Cochrane Database Syst Rev 2015(6):Cd002280. DOI: 10.1002/14651858. CD002280.pub2.

22. Marinho VC, Worthington HV, Walsh T, et al. Fluoride varnishes for preventing dental caries in children and adolescents. Cochrane Database Syst Rev 2013(7):Cd002279. DOI: 10.1002/14651858. CD002279.pub2.

23. Buzalaf MAR, Pessan JP, Honorio HM, et al. Mechanisms of action of fluoride for caries control. Monogr Oral Sci 2011;22:97-114.

24. Milgrom P, Zero DT, Tanzer JM. An examination of the advances in science and technology of prevention of tooth decay in young children since the surgeon general's report on oral health. Acad Pediatr 2009;9(6):404-409. DOI: 10.1016/j.acap.2009.09.001.

25. Berkowitz RJ. Causes, treatment and prevention of early childhood caries: a microbiologic perspective. J Can Dent Assoc 2003;69(5): 304-307. 
26. Ogard B, Seppa L, Rolla G. Professional topical fluoride applications-clinical efficacy and mechanism of action. Adv Dent Res 1994;8(2):190201. DOI: $10.1177 / 08959374940080021001$.

27. Marinho VC. Cochrane reviews of randomized trials of fluoride therapies for preventing dental caries. Eur Arch Paediatr Dent 2009;10(3):183-191. DOI: 10.1007/BF03262681.

28. American Academy on Pediatric Dentistry Liaison with Other Groups Committee. Guideline on fluoride therapy. Pediatr Dent 2013;35(5):E165-E168.
29. Milgrom $P$, Tut $O$, Rothen $M$, et al. Efficacy evaluation of an anticaries varnish: protocol for a phase II randomized controlled trial. BMJ Open 2017;7(6):e017866. DOI: 10.1136/bmjopen-2017017866.

30. Goyal A, Grover A, Gauba K, et al. A community-based pragmatic, controlled trial for preventing and reducing oral diseases among 1-6-year-old children visiting anganwadi centers, under the integrated child development scheme, India. BMC Public Health 2019;19(1):1626. DOI: 10.1186/s12889-019-7874-y. 